\title{
REAKTUALIZACJA TRAUMATYCZNEJ PAMIĘCI ZBIOROWEJ WE WSPÓŁCZESNEJ LITERATURZE UKRAIŃSKIEJ
}

\author{
OKSANA PUCHOŃSKA ${ }^{1}$ \\ (Uniwersytet im. B. Grinczenki w Kijowie)
}

Słowa kluczowe: pamięć, literatura, posttotalitaryzm, postkolonializm, kultura, trauma, wojna

Keywords: memory, literature, post-totalitarianism, post-colonialism, culture, trauma, war

\begin{abstract}
Abstrakt: Oksana Puchońska, REAKTUALIZACJA TRAUMATYCZNEJ PAMIĘCI ZBIOROWEJ WE WSPÓŁCZESNEJ LITERATURZE UKRAIŃSKIEJ. „PORÓWNANIA” 15, 2014, T. XV, s. 209-217. ISSN 1733-165X. Przedmiotem analizy są osobliwości aktualnego stanu kultury i literatury Ukraińców, jako ważnych aspektów w badaniu sytuacji posttotalitarnej. Autorka podkreśla krańcową odmienność w wyeksponowaniu pojęć antytotalitaryzmu i totalitaryzmu, dekolonizacji i postkolonializmu. Skupia się także na reprezentacji owych pojęć we współczesnej literaturze ukraińskiej. Znaczną uwagę zwraca na kwestię traumatycznej pamięci, która reprezentuje doświadczenie wojny w świadomości jednostki i zbiorowości. W interpretacji utworów literackich autorka stosuje metodę memory studies, omawiając jednocześnie specyfikę narodową badanych zjawisk. Dokonuje analizy na podstawie powieści Sergiya Germana Inge (IHזe), Volodymyra Lysa Solo dla Solomiyi (Соло для Соломіi)) oraz Juriya Vynnyčuka Tango smerti (Танго смерті).
\end{abstract}

\begin{abstract}
Oksana Pukhonska, RE-ACTUALIZATION OF THE COLLECTIVE MEMORY IN THE MODERN UKRAINIAN LITERATURE. "PORÓWNANIA" 15, 2014, Vol. XV, p. 209-217. ISSN 1733-165X. The article is dedicated to the peculiarities of the modern Ukrainian culture and literature in the process of post-totalitarian and post-colonialistic studies. The author points to the differences in the concepts of antitotalitarianism and post-totalitarianism, de-colonialism and post-colonialism. She tries to research the representation of the concept of war in the modern Ukrainian literature. Much attention is paid to traumatic memory in the context of Memory Studies. The analysis is carried out on the basis of the following novels: Inge by Sergiy German, Solo for Salomea by Volodymyr Lys and Tango of death by Yuriy Vynnyčuk.
\end{abstract}

\footnotetext{
${ }^{1}$ Correspondence Address: o.pukhonska@kubg.edu.ua
} 
Totalitaryzm sowiecki, którego celem było niszczenie nierosyjskich kultur narodowych, przyspieszył procesy ideologicznego emancypowania się grup etnicznych oraz narodów i w ostatecznie wpłynął na rozwój tożsamości narodowych w epoce określonej jako epoka post (postkolonialna, postmoderna, posttotalitarna). Wszystkie te zjawiska opatrzone wspólnym prefiksem post mają różne zakresy i znaczenia, jednak w obrębie kultury ukraińskiej występują jako równorzędne czynniki służące do wypierania traumatycznego doświadczenia pochodzącego z dalszej i bliższej przeszłości. Być może, w odniesieniu do tego problemu bardziej wypadałoby mówić o dekolonizacji i antytotalitaryzmie, jak również o reinterpretowaniu pamięci narodowej poprzez próby marginalizowania ideologii komunistycznej. Jednak w kulturze ukraińskiej taka praktyka nie jest dość skuteczna a relikty przeszłości są wciąż dość silne.

Stan studiów postkolonialnych, jak zauważa profesor Bogusław Bakuła, ukazuje gotowość pewnej części ukraińskiego społeczeństwa do ocenienia własnej przeszłości, w tym także do jej rewizji². Traumatyczne doświadczenia przeszłości, nad którymi się zastanawiamy w tym artykule, przejawiają się w strukturze i charakterze pamięci narodowej i indywidualnej. Poprzez oba rodzaje pamięci można uchwycić i zatrzymać najbardziej gruntowne przejawy historycznej traumy. Pamięć to nie tylko mechanizm przechowywania, lecz także zapominania. W swoim czasie David Hume podkreślał, że podstawą każdego społeczeństwa są przemoc i bezprawie, zatem dominujący system społeczno-polityczny dosyć często opiera się na konstruowaniu ideologii umożliwiającej działanie mechanizmów zapominania przez naród własnych korzeni ${ }^{3}$. Niewątpliwie, doświadczenie totalitaryzmu przez Ukraińców, a zwłaszcza przeżyte $\mathrm{w}$ wieku XX wojny światowe, bolszewickie represje, Wielki Głód, stały się ich traumą zbiorową. Wydarzenia te ukształtowały psychotyp współczesnego Ukraińca, aczkolwiek pełna wiedza o nich przedostała się do zbiorowej świadomości bardzo późno. Jest sprawą zrozumiałą, że uwolnienie się od tak silnego zespołu doświadczeń, składających się na traumę zbiorową stanowi warunek wyjścia z kolonialnej zależności, przede wszystkim na poziomie mentalnym i na poziomie zbiorowej podświadomości.

W tym strategicznym procesie przezwyciężania przez ukraińskie społeczeństwo wpływu czynników zależnościowych ważnym argumentem jest literatura piękna. W tradycyjnym ujęciu naród ukraiński został ukształtowany właśnie na podstawie i wobec wzorców kulturowych, zwłaszcza literackich4. Według Ewy Thompson, „literatura jest istotnym budulcem, a także wyrazem tożsamości naro-

${ }^{2} \mathrm{Na}$ podstawie wykładu gościnnego pt. „Problematyka postkolonialna w aktualnym ujęciu”, wygłoszonego przez prof. Bogusława Bakułę w Kijowskim uniwersytecie imienia Borysa Grinczenki 20 listopada 2013 roku. Zapis własny - O.P.

${ }^{3}$ D. Hume, Traktat pro luds'ku prirodu. Kiïv 2003, s. 328.

${ }^{4}$ O. Hnatiuk, Pożegnanie z Imperium. Ukraińskie dyskusje o tożsamości. Lublin 2003, s. 33-34. 
dowej. Postawy w obliczu zwycięstwa i porażki różnią się znacznie w przypadku poszczególnych narodów, co częściowo opiera się na wzorcach upamiętnionych"5. W tym duchu wypada tutaj potraktować poszczególne dzieła literatury współczesnej, które zapowiadają się na próby reanimacji pamięci o przeszłości narodu, a zwłaszcza o doznanych przez niego porażkach historycznych i przeżytych traumach. W ramach określonego zadania warto zaakcentować te główne aspekty, w których zakresie przejawia się kulturowa amnezja narodu. Są one następujące:

- celowe wyrzeczenie się tragicznej przeszłości przez przemilczenie;

- naturalna zmiana pokoleniowa, w której każda kolejna generacja, w wyniku rezygnacji z doświadczeń poprzedników niewiele wie o przeszłości, ale jej trauma w tym przypadku może być nawet głębsza z powodu braku wiedzy o tym, co było wcześniej;

- sztuczne zastępowanie traumatycznej pamięci przez ironię, bufonadę, karnawat;

- przezwyciężanie traumy przez reaktualizację oraz docelowe przypominanie.

Wymienione kryteria odpowiadają trzem poziomom pojmowania problemu pamięci, mianowicie cechują totalitarne, antytotalitarne i posttotalitarne segmenty w kulturze.

Jak zauważa Ewa Thompson, dziś jest bardzo potrzebna taksonomia, która pozwoliłaby na stanowcze oddzielenie intencji skierowanych na tworzenie kultu historii oraz tradycji określonego narodu od tych, które są skierowane na potwierdzenie autorytetu narodu osiąganego $\mathrm{w}$ drodze podboju innych narodów ${ }^{6}$. Masowe represje systemu sowieckiego z lat 20.-30. XX wieku stanowily polityczne tabu. Wspominanie o nich groziło bezpieczeństwu i życiu każdej jednostki, bez względu na jej pozycję. To spowodowało zaburzenie pamięci zbiorowej w następnych etapach historycznych. Pokolenie, które zostało urodzone po wojnie, nie znało ani przyczyn, ani skutków przedwojennego terroru. Pamięć o nim została niemal wyparta $z$ jego świadomości. Dlatego pokolenie to postrzegało wojnę jako pole wyłącznie bohaterskiej chwały, a radzieckich żołnierzy jako wyzwolicieli od okupacji niemieckiego nazizmu, to znaczy bohaterów - w żadnym wypadku jako sprawców niewoli. Pewne próby odzyskania właściwej pamięci były podejmowane w latach 60. i 70. XX wieku, ale bardzo nieśmiało, spontanicznie i przypadkowo. Tragiczne doświadczenie z przeszłości (mamy na myśli przede wszystkim wojny i represje) dało się poznać jako czynnik kształtujący określone grupy społeczne, zwłaszcza intelektualistów z pokolenia lat 60., z których wielu doznało poniżenia przez przywrócony po II Wojnie system represyjny.

Poczynając od drugiej połowy lat 80., totalitarna przeszłość Ukrainy jest stopniowo demaskowana. $W$ okresie pierestrojki jeszcze nie wyobrażano sobie jej jako

${ }^{5}$ E. Thompson, Trubadurzy imperium. Literatura rosyjska i kolonializm. Przeł. A. Sierszulska. Kraków 2000, s. 16.

${ }^{6}$ Ibidem, s. 14. 
przeszłości, ale pierwsze objawy pożegnania z totalitarnym modelem kultury obserwujemy już w zjawiskach ostrej ironii oraz karnawału, które występują w młodej literaturze ukraińskiej na przełomie lat 80.-90. XX wieku. Nie chcąc zagłębiać się $\mathrm{w}$ przyczyny i skutki represji totalitarnych, młodzi autorzy, którzy akurat w tym czasie wchodzą w świat już innej literatury, obalają totalność ówczesnego języka propagandy przez to, że uciekają się do parodiowania socrealistycznego kanonu. $\mathrm{W}$ ten sposób ich obronna reakcja przed komunizmem stała się głosem pokolenia, które nie było jeszcze gotowe do uświadomienia sobie głębokiej traumy przeszłości i do poważnego ustosunkowania się wobec niej.

Próba odzyskania tożsamości narodowej, niewywodzącej się ze źródeł totalitarnych, w twórczości niektórych młodych pisarzy (szczegółnie członków Bu-Ba-Bu - Juriya Andrukhovyča, Oleksandra Irvantsia i Viktora Neboraka) przyczyniła się do stworzenia obrazu klauna, który tańczy na kościach zmarłych, rezygnując jednocześnie $\mathrm{z}$ perspektywy poważnego rozliczenia się $\mathrm{z}$ historią zbiorową. $\mathrm{Z}$ innej strony, klaun ten już rozumie, że jeśli zerwie zasłonę z przeszłości, wówczas będzie zmuszony przeżyć to raz jeszcze, bez maski, patrząc historii prosto w oczy. Dlatego początki dekolonizacji (detotalitaryzacji) w literaturze ukraińskiej są postrzegane jako ucieczka od traumy przeszłości. Zgadzamy się, że w tym przypadku głównym akcentem, skierowanym $\mathrm{w}$ stronę przewartościowania przeszłości, jest gra. Model życia bohaterów (a także ich drogi życiowe) w nowoczesnej interpretacji teoretycznej przyjmuje kształt modelu ryzyka, gry z losem, z warunkami społeczno-politycznymi, wreszcie z samym życiem, przy założeniu, że można liczyć na minimalne możliwości wygranej. Johann Heyzynha [Huizinga - red.] stwierdzał, że jeśli przeanalizować dążenie jednostki do wiedzy bez granic, to tak czy inaczej przybierze ono kształt gry ${ }^{7}$.

Dopiero w latach 90. Ukraińcy zaczęli poważnie zastanawiać się nad problemem braku wewnętrznej wolności jednostki, co jest zwrotnym skutkiem uświadomienia przez nich ducha narodowego oraz narodowej tożsamości. Bohaterka powieści Oksany Zabužko Badania terenowe nad ukraińskim seksem dochodzi do wniosku, że niewolnicy nie rodzą wolnych dzieci. W sytuacji pozornej wolności, uzależnienie psychologiczne, wychowanie pod presją reżimu totalitarnego, powoduje podwójną traumę, której istota tkwi w uświadomieniu sobie jednocześnie stanu zniewolenia (1) i bycia wytwórcą ducha tej niewoli (2). Tamara Gundorova twierdzi, że „luka pokoleniowa w postkolonialnej literaturze przejawia się bądź to, jako tragiczna łuna byłych grzechów ojców, bądź jako ironiczna maska samych bohaterów"8. Taką właśnie postawę obserwujemy w utworach współczesnych autorów ukraińskich Yurija Vynnyčuka, Yurija Andrukhovyča, Jevgenii Kononenko, Sergiya Žadana.

\footnotetext{
7 J. Heyzynha, Homo Ludens. Stat'i po istorii kul'tury. Per. D. Silvestrov. Moskva 1997, s. 7.

8 Ibidem, s. 116.
} 
Z początkiem nowego tysiąclecia zmianie uległy paradygamaty kulturowe, nie tylko na Ukrainie, ale również w całym świecie. Antropologiczny wymiar relacji społecznych, kulturowych czy w świecie sztuki powoduje, że w centrum uwagi znalazła się jednostka, która kreuje samą siebie i otoczenie wokół siebie. Spójność takiej postaci jest możliwa dopiero pod warunkiem nawiązania relacji z przeszłością, co zresztą rzutuje na przyszłość. Dwudziestoletnia historia prób uwolnienia się Ukraińców od kolonialnej przeszłości, zwłaszcza od skutków totalitarnej ideologii imperium sowieckiego zaowocowała nieuchronnym doświadczeniem reinterpretacji własnej historii, zarówno w jej zbiorowym ujęciu, jak i tej charakteryzującej się zróżnicowanymi obrazami pamięci. W literaturze początku XXI stulecia podejmuje się liczne próby reanimacji pamięci narodowej na postawie zrozumienia najbardziej tragicznych zdarzeń z przeszłości. W ten sposób przywróceniu ulega nie tylko narodowa, lecz również ogólnokulturowa pamięć, naznaczona przez tragiczne doświadczenia totalitarnej historii. Zjawisko te występuje zwłaszcza w powieściach Tango śmierci Yuriya Vynnyčuka (tłumaczonego w Polsce), Inge Sergiya Germana oraz Solo dla Sołomiji Volodymyra Lysa.

Niemiecka badaczka literatury Aleida Assmann w swojej koncepcji memory studies wyróżnia dwa rodzaje kulturowej pamięci: pamięć jako magazyn oraz pamięć funkcjonalna. Druga zostaje zorientowana na przyszłość i posiada charakter selektywny, ponieważ jej użytkownicy dokonują wyboru z magazynu pamięci tego, co jest aktualne dziś. Według Assmann, pamięć jest dostępna nam jedynie w efekcie sztuki zapamiętywania, zdolności do zachowania informacji bądź też jako czynna siła przekształcająca kulturę?.

W powieści Yuriya Vynnyčuka Tango śmierci ${ }^{10}$ pamięć jest swoistą bohaterką, z pewną szczyptą mistycyzmu, ponieważ ukrywa w sobie tajemnicę zamkniętego kręgu życie - śmierć - życie. Cała fabuła utworu skierowana na odtworzenie procesu wspominania zdarzeń z dawnych lat. Autor zarysowuje zagadkowy problem reinkarnacji, lecz główną uwagę poświęca okresowi drugiej wojny światowej oraz stratom wśród Ukraińców, Żydów, Polaków, Niemców, którzy stali się ofiarami masowych zbrodni zrealizowanych według planów Hitlera i Stalina. Obok umiejętnie poprowadzonej intrygi fabularnej oraz kolizji miłosnych, autor powieści obrazuje tragedię masowych represji oraz zagłady Żydów, Polaków, Ukraińców w obozach koncentracyjnych (według obliczeń historyków, we lwowskim obozie Janowskim zostało zamordowano około dwustu tysięcy osób). W powieści Wynnyczuka rzeczywiste fakty historyczne przeplatają się z historią wyimaginowaną, odzwierciedlającą charakterystyczne wyobrażenia autora o dziejach przedwojennego i wojennego Lwowa. Przecież „każda reprezentacja historii <...> zawiera w sobie wyobrażane powtórzenie doświadczonego i uświadomionego. Jest to re-

${ }^{9}$ A. Assmann, Prostori spogadu. Formaty ta transformacii kul'turnoï pamâtì. Per. K. Dmitrenko, L. Doroničeva, O. Judìn. Kiïv 2012, s. 145.

10 Y. Vynnyčuk, Tanǵo smertì, L'vìv 2012, s. 379. 
prezentacja historii odbieranej z punktu widzenia teraźniejszości, co $\mathrm{w}$ pewien sposób ulega prze-opowiadaniu przez współczesnych ludzi i powtórzeniu przez wyobraźnię ${ }^{11}$. Pisarz kładzie uwagę na próbie przypomnienia przeszłości poprzez odszyfrowania formuły dawnego zapomnianego tanga, ale tkwi w tym również plan przełamania amnezji kulturowej. I chociaż przypomnienie przeszłości kojarzy się z traumą sprzed lat, to jednak właśnie ono daje szansę przezwyciężenia urazu.

Powieść Sergiya Germana Inge przynosi ciekawy materiał dla analizy osobliwości totalitarnej traumy zarówno na poziomie jednostki, jak i całego pokolenia. Chodzi o niemiecką dziewczynę Inge, ukochaną Bohdana Staszyńskiego, radzieckiego zwiadowcy i agenta, zabójcy Stepana Bandery i Lwa Rebeta. Autor poświęca sporo uwagi relacjom młodych bohaterów na tle społeczeństwa totalitarnego (ta kolizja jest interesująca sama w sobie), ich charaktery i wzajemne stosunki zostają uwypuklone na tle właściwej doby historycznej. Te relacje siłą rzeczy wydają się nacechowane duchem niewoli i przymusu, co przyczynia się do nieuniknionej traumy w osobistym doświadczeniu obu bohaterów.

Poza tym, autor zarysowuje tragiczne tło wojny, co niezwykle komplikuje losy Inge i Bohdana. W tym przypadku wojna jest źródłem lęku i przerażenia, ale jej trudne doświadczenie okazuje się niezbędne dla zbudowania zbiorowej tożsamości. Jak twierdzi Ewa Thompson, wojny odgrywają „kluczową rolę w wykuwaniu tożsamości narodowej, bez względu na to, czy były wygrane, czy przegrane. Pamięć tych wojen została retorycznie wyidealizowana przez elity etniczne"12. Wobec losu bohaterów powieści wojna potraktowana zostaje jako siła destrukcyjna, rujnująca ludzkie relacje i traumatyzująca jednostkę. Wywołuje przecież fobie podobne do tej, doznanej przez Inge: „,... Mnie do tej pory śni się wojna. Jakby tak na prawdę się nie skończyła, a mnie może doganiać w każdej chwili"13. Aktualizując temat wojny, autor dostarcza innej interpretacji, jako że trwanie wojny w wyobraźni bohaterów przedłuża się w nieskończoność i wywołuje urazy w sferze psychicznej. W świadomości Inge trauma wojny powiela się w powojennym doświadczeniu, gdyż Niemcy dostają się pod okupację Związku Sowieckiego. Pisarz pokazuje kontrast standardu życia w Niemczech Zachodnich i Wschodnich, gdzie siłą narzucono ideologię komunistyczną, gdzie istniało ograniczenie wolności i podstawowych praw jednostki. Jeżeli bohaterka Oksany Zabužko stanowczo twierdzi, że niewolnicy nie rodzą wolnych dzieci, to Inge wciąż przekonuje, że z momentem urodzenia dziecka stanie się wolną osobą („twoja wojna skończy się z urodzeniem dziecka"14). Choć jesteśmy skazani na trwanie z trudnymi wspomnieniami, to jednak chciałoby się wierzyć, że „dzieci nas przekształcają".

\footnotetext{
11 T. Gundorova, op. cit., s. 117.

12 E. Thompson, op. cit., s. 16.

${ }^{13}$ S. German, Inge, Kiïv 2012, s. 94.

${ }^{14}$ Ibidem, s. 95.
} 
Inna sprawa wiąże się z Bohdanem (jako sowiecki agent występuje on także pod pseudonimem Józef). Dla Inge wojna stała się punktem wyjściowym jej rosnącego lęku wobec życia, ale przedtotalitarne doświadczenie wolności wywołuje $\mathrm{u}$ niej sprzeciw wobec działalności władz komunistycznych, narzucających niewłaściwy tryb życia i ograniczających prawa oraz wolność zwykłych obywateli Niemiec. Dlatego tożsamości Inge, jako obywatelki i Niemki, nie uda się komunizmowi zniszczyć bez walki. W przypadku Bohdana-Józefa mamy do czynienia $\mathrm{z}$ zupełnie odmienną mentalnością. $\mathrm{W}$ jego psychice nawarstwiło się kilka doświadczeń o znaczeniu traumatycznym, co komplikuje czy nawet wręcz blokuje pespektywę protestu. Bohater wyznaje: „Uwierzyłem, że walczyć z systemem sowieckim nie ma sensu. To jest to samo, co zatrzymać pociąg bez kierowcy, który pędzi w twoją stronę bądź zatrzymać chmurę, z której lada chwila będzie lał deszcz"15. Udanym chwytem autora jest skonfrontowanie tych absolutnie różnych bohaterów i ich postaw życiowych,. Wola i zdecydowanie Niemki zostają przeciwstawione uległości Bohdana wobec siły i okoliczności życia. Jak uważa Paul Ricoeur, wola do wspomnień jest dowodem na jedną z najważniejszych funkcji aktu pamięci, która tkwi w walce jednostki z zapomnieniem ${ }^{16}$.

Vynnyčuk akcentuje chronologiczny aspekt traumatycznej pamięci, z kolei German apeluje do aspektów doświadczenia totalitaryzmu i mentalności narodowej. Natomiast Volodymyr Lys w powieści Solo dla Solomiyi17 przedstawia posttotalitarne ujęcie Ukrainy jako próbę przewartościowania przeszłości z punktu widzenia zwykłego, pospolitego człowieka. Historia rodu zostaje tutaj utożsamiana z biografią jednej bohaterki, zwykłej chłopki Sołomiji z Wołyńskiego Polesia. Wspólną cechą wszystkich trzech omawianych książek jest przezwyciężanie przez jednostkę traumatycznego doświadczenia wojny. Jednakże wojna nie tylko dostarcza traumy, także decyduje o wyborach życiowych bohaterów, a więc okazuje się sprawdzianem wytrwałości i moralnej siły człowieka. W przypadku Solomiyi doświadczenie traumatyczne wciąż prześladuje bohaterkę, począwszy od poczucia śmiertelnego zagrożenia doznanego podczas próby wyzwolenia przyjaciółki z niemieckiej niewoli jeszcze na początku wojny, poprzez zgon męża i ukochanego, co ujawniło różne linie frontu (pierwszy był sowieckim żołnierzem i zginął na zachodzie, drugi zaś walczył w oddziale partyzantów UPA, broniąc wsi przed komunistycznymi władzami). Traktowanie ukraińskiej kobiety jest $\mathrm{w}$ powieści Lysa całkiem konwencjonalne, charakterystyczne dla okresu totalitaryzmu, to znaczy, że jest odbierana jako „obiekt seksizmu” (G. C. Spivak). Piękno i uroda Solomiyi, jej charyzma i urok powoduje, iż staje się ona obiektem pożądania najpierw

15 Ibidem, s. 115.

${ }^{16}$ P. Ricoeur, Pamât', istoriâ, zabvenie. Per. I. Blauberg, S. Vdowina, O. Mačulskaâ, G. Tavriźân. Moskva 2004, s. 55.

17 V. Lys, Solo dl'â Solomiï. Kharkìv 2013, s. 368. 
braci sąsiadów, później niemieckiego żołnierza, następnie urzędnika partyjnego z powiatu, starosty itd. $\mathrm{W}$ tym przypadku całkiem do rzeczy byłoby przypomnienie $\mathrm{w}$ nieco sparafrazowanej postaci pytania postawionego przez Gayatri Chakravorty Spivak: „czy subaltern (jako kobieta) może mówić?”. Oddanie uzależnionemu prawa do głosu zwykle naraża go w historii na niebezpieczeństwo, co wynika $\mathrm{z}$ dominacji dyskursu męsko-imperialnej formacji ideologicznej ${ }^{18}$. Jednak Lys akcentuje to pytanie inaczej. Ze względu na kobiecą istotę ukraińskiej nacji (według Nily Zborovskiej) pisarz stawia w centrum reinterpretacji dziejów XX wieku właśnie kobietę, doceniając z jednej strony jej sakralizowaną rolę strażniczki ogniska domowego i rodziny, lecz z innej strony pokazując kobietę, jako najbardziej bezbronną (i do tego jeszcze milczącą, pozbawioną prawa do wypowiedzi o własnych krzywdach) ofiarę systemu totalitarnego. Kobieta w tamtych czasach, zastępując zabitych ojców, braci, mężów oraz synów, brała na swoje barki odpowiedzialność za wychowanie kolejnego pokolenia i za los całego narodu. Oprócz tego, trauma spowodowana utratą krewnych, przede wszystkich mężczyznobrońców, powiela się $\mathrm{w}$ efekcie ciągłego zagrożenia gwałtem $\mathrm{w}$ sytuacji, kiedy uroda kobiety jest postrzegana jako towar do sprzedawania $\mathrm{w}$ relacjach $\mathrm{z}$ władzami. Volodymyr Lys nie tylko nawiązuje do lekceważonego w okresie totalitarnym urazu kobiety, lecz również próbuje się zastanowić nad tym problemem z punktu widzenia współczesności. Tu chodzi o takie rozumienie historii, które przybliża ją dzisiejszemu człowiekowi i czyni ją namacalnym, osiągalnym doświadczeniem, pomimo czasowego oddalenia. Według Keith Jetkins, współczesne pojęcie historii przewiduje nie tyle wiedzę o przeszłości, ile rozważanie na temat tego, co przeszłość oznacza w dyskursie teraźniejszości, a to z kolei pobudza jednostkę do ciągłego apelowania do historii i dokonywania reorientacji na tym obszarze wiedzy czy też dostosowywania jej do aktualnych potrzeb ${ }^{19}$. W tym kontekście można powiedzieć, że Lys w powieści Solo dla Solomiyi proponuje współczesnemu czytelnikowi dokonanie przewartościowania dziejów narodu ukraińskiego $\mathrm{w} X \mathrm{XX}$ wieku poprzez historię życia chłopki, kobiety, poprzez jej przemilczane krzywdy i urazy. Proponuje, by zastanowić się, na ile doświadczenie Solomiyi zasługuje na akceptację bądź potępienie i jak może być potraktowane w aktualnych, radykalnie różnych od tych dawnych, okolicznościach.

Podsumowując, warto podkreślić, że posttotalitarna trauma zobrazowana jest w utworach współczesnej ukraińskiej literatury w sposób specyficzny. Intencje pisarzy ukraińskich w założeniu sprowadzają się do pokazywania traumy w szerszym kontekście jej recydywy we współczesnej sytuacji kulturowej. Okazuje się, że resentyment z przeszłości pobudza pisarzy, by do niego ponownie apelować.

${ }^{18}$ G. Ch. Spivak. Czy može piddporâdkovane promowlâty? Per. M. Zubritska. W: Antologiâ switovoï literaturno-kritičnoï dumki XX stolitt'a. Red. M. Zubritska. L'vìv 2001, s. 716.

${ }^{19}$ K. Jenkins, Re-thinking History. London 2008, s. 80-81. 
A najważniejsze, by z punktu widzenia teraźniejszości przemyśleć i wyprzeć traumę pochodzącą z okresu totalitaryzmu. Nagłaśnianie tych aspektów w książkach pisarzy ukraińskich wygląda na zjawisko nie tyle charakterystyczne, ile mające znaczenie systemowe czy wręcz zasadnicze. Można założyć, iż w zasadzie proces dekolonizacji $\mathrm{w}$ literaturze pięknej jeszcze nie przeszedł $\mathrm{w}$ wymiar post, aczkolwiek został ukształtowany w tej perspektywie. Myślę, że za wcześniej byłoby mówić o posttotalitarnym wymiarze kultury ukraińskiej, oczywiście w kompletnym znaczeniu tego pojęcia. Wydaje się, że pierwsza faza tego procesu, polegająca na bezpośredniej i raczej formalnej dekolonizacji, już minęła, a trwała ona przez pierwsze dwa dziesięciolecia dziejów niepodległej Ukrainy. Druga faza, charakteryzująca się głębszą refleksją nad doświadczeniem kolonializmu, dopiero się zaczyna, w jej obrębie będzie się oceniać nowsze powieści Yuriya Vynnyčuka, Sergiya Germana oraz Volodymyra Lysa. Nowa wizja przeszłości stanie się możliwa dopiero pod warunkiem istotnego przewartościowania historii, wyeksponowania jej skutków ubocznych, przemyślenia błędów i osiągnięć z punktu widzenia epoki posttotalitarnej. 